\title{
ストレスと動脈硬化*
}

石川中**

\section{I. 動脈硬化と性格}

ストレスと動脈硬化の関係をストレスと高血圧, および冠動脈疾患の関係から論じたいと思う.

身体疾患と性格傾向の間に一定の関係のあるこ とをはじめて明らかにした，アメリカの心身医学 のパイオニアである F. Dunbar は, 狭心症患者 に強迫傾向, 敵意や怒りをあらわさない, 受動的 な攻撃性等の性格特長をあげたが，その後多くの 学者が多彩な性格傾向を指摘した。

すなわち狭心症性格として, 仕事について欲求 不満がありストレスの多いこと, 同じ仕事をして いる同僚に対して競争的に仕事をする傾向がある こと，静かな休暇をとろうとしない傾向があるこ と, 夫婦間の問題の多いこと, 社会的に努力家型 の人が多いことを述べている.

一方，1958 年に Rosenman と Friedman は， Dunbar らが考えたように，一定の性格と一定の 病気の発生の間に一対一の対応を求めるよりは, 一定の行動型と一定の病気の発生との間に対応を 求めるべきであろうと考えて, これまでの学者の 述べる冠疾患者の性格傾向を総合して，これらを さらに行動面まで広げて, 冠動脈硬化症ないし狭 心症患者は, 彼らが behavior pattern A と呼んだ 行動型, 寸なわち野心的で, 競争的で, 仕事に没 頭し, 仕事のメ切のストレスを受け, 常に行動に かりたてられており, イライラして, 早口で落着 きがなく気が短いなどの特徵を有しており，身体 面としては高コレステロール，高血圧などの要因 があるとした1)。

*1983年 7 月, 第15回日本動脈硬化学会において発表 ** 東京大学医学部
そして Framingham Study においてもこの behavior pattern A のグループに, prospective study でリラックスしたパターン B に比べて, 2 倍の冠疾患の発生があることを明らかにした ${ }^{2)}$.

他方, 高血圧についても同様に性格傾向につい ての研究があり, 抑圧された敵意, 攻撃的傾向, 不安, 抑うつ等, 多くの学者がほぼ一致した見解 を述べている.

一方 Ostfeld は, 高血圧患者にロールシャッハ テスト, MMPI などを行って, 健常者に比して個 有の性格傾向は示さなかったと報告している ${ }^{3,4)}$.

われわれも高血圧患者に MMPI を行って, 健 常者との間に差を認めなかった ${ }^{3,4)}$.

高血圧患者の性格傾向を高血圧発症の一次的な 原因としてとらえるためには, prospective study を行う必要がある.

そこでわれわれは, 1961 年に都内某官庁の日 常勤務者について第一回の循環器集団検診を行い, 10 年後の 1971 年にその追跡調查を行った.

1961 年の第一回集団検診は, 40 歳以上の男 子について, その対象集団のうちから 118 名の radam sampling を行い, この全員に循環器精密 検査 (血圧, 嗜好品, その他の調查, および家族 歴, 既応歴などの聴取) と同時に, Cornell Medical Index の M から $\mathrm{R}$ 項までの精神的自覚症に ついての調査を行い，そしてそのうち48 名につ いて, 1971 年の 10 年後に同様の循環器集検を行 うことができた.

その結果, 1961 年に正常血圧であり, 10 年後 においてもなお正常血圧であった 15 名において は, CMI 高点者は $33 \%$ であったが, 正常血圧か ら高血圧に移行した 5 名は全て CMI 高点者だっ 
た.また高得点を示した CMI の項目としては， 社会的不適応，過敏，怒りがあげられる.

以上の 10 年間の prospective study から, 高血 圧の発症に対し精神因子が一次的な病因的意義を 有する症例のあることを明らかにしたが. 3 例に ついて, 新たに心電図上の器質的変化が発生した ことが示され，これは心理因子によって発症した 高血圧が, 動摇性高血圧から固定性高血圧に, そ してさらに臓器障害にまで進行する可能性を示し ている.

なおこれらの症例には全て高血圧の遺伝歴が あり, 高血圧の発症には, 素質と気質のオーバー ラップが原因として関与すると考えられる5).

循環器心身症の心理因子についての研究は, 日 本においても性格傾向から行動パタンへと移行し つつある. 日野原, 篠田らは，1975 年に日本人 の虚血性心疾患患者にもタイプ A の多いことを 発表し ${ }^{6)}$, その後関口, 長谷川は生活調查表によ $\eta^{7)}$, 五島, 保坂らは東海大式日常生活行動調査 表により ${ }^{8)}$ ，それぞれ虚血性心疾患患者に Rosenman らの行動パタンA の多いことを明らかにし た.

またわれわれは, 身体, 精神状態, パーソナリ ティ，環境等の要因を総合的にとらえ得る質問紙 法 JMI を使って, NCA, 高血圧にっきプロフ ィールを比較して二者に有意な差のあることを明 らかにした ${ }^{9)}$ 。または，虚血性心疾患患者に，東 海大式行動調查表および交流分析のエゴグラムを

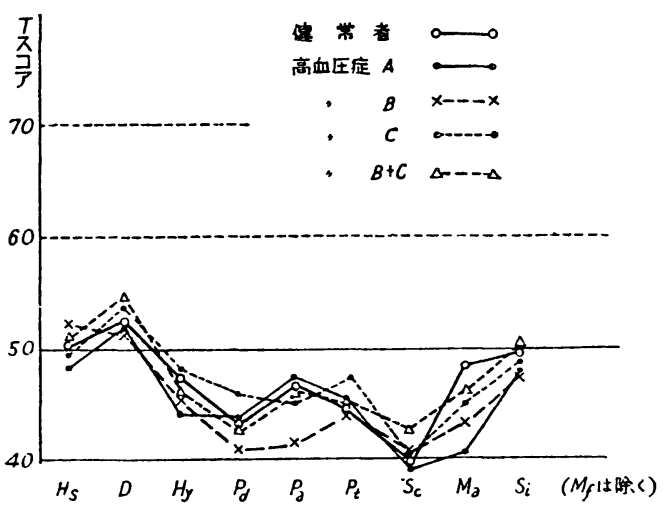

Fig. 1 健常者および高血圧症各群の MMPI 平均值プ ロフィール。
用いて, NCA, 高血圧, 冠動脈疾患のプロフィー ルを比較し，三者に違いのあることを明らかにし た。

以上, 高血圧および冠動脈疾患患者には, 社会 生活に対する過剩反応のあることが判る.

\section{II. ストレスと動脈硬化}

一般に循環器系は, 心理的および物理的ストレ スに対して敏感に反応する. その際のメディエー ターとして，アドレナリンおよびノルアドレナリ ン，すなわちカテコラミンが最も重視されている.

東北大心療内科の鈴木らは, 機能的心脈管疾患 として, 心臓神経症, NCA 等について MDT (mirror drawing test) の負荷を与えて，ストレス に対する反応として, 精神神経症に近い心臟神経 症の場合には, 心拍数, 血圧等に変動がなく, 他 方心身症としての NCA や潜在性冠不全では，心 拍数増加, 血圧上昇とともに心電図 $\mathrm{ST} \cdot \mathrm{T}$ 変化 を認め, またメディエーターの面でも，心臟神経 症では変化なく, NCA ・潜在性冠不全ではカテ コールアミンの増加が認められたと報告している. なお， $\beta$ ブロッカーを投与すると，MDT によ

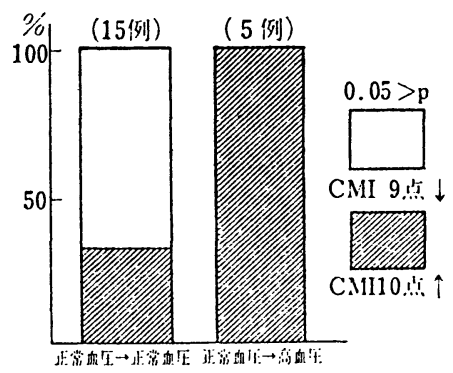

Fig. 2

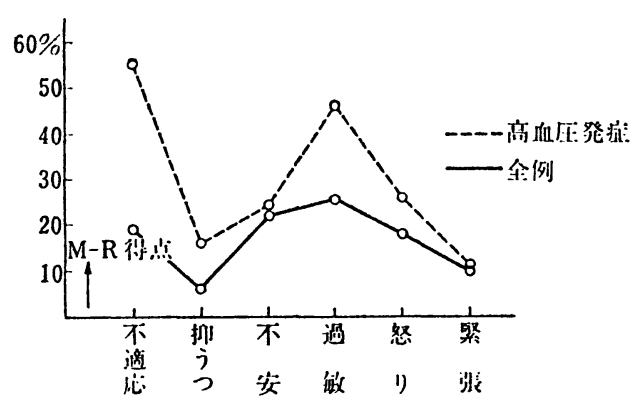

Fig. 3 高血圧発症と CMI (M-R) プロフィール. 
る心拍数，血圧の反応は顕著に抑圧された ${ }^{10)}$.わ れわれは狭心症患者に対し，心理ストレスとして 生活史面接, 労作ストレスとして階段昇降負荷を 行い, 負荷前後の患者の血圧, 心拍数, 動脈血 $\mathrm{pH}$, 酸素分圧, 炭酸ガス分圧, 乳酸, 焦性ブド ウ酸值等を测定した。

結果は, 血圧と心拍数の反応については, 心理 ストレスの場合はまず血圧が上昇し，ついで心拍 数が増加したが, 労作ストレスの場合には, 両者 は同時に上昇増加する，そして心理ストレスの場 合は血圧, 労作ストレスの場合は心拍数の方がよ り顕著に増加する.

またこれを動脈圧ガス分圧および代謝面からみ ると, 心理ストレスの場合には, 軽度の換気機能 低下が認められる以外には著変はないが, 労作ス トレスの場合には, 労作性のアチドーシスがおこ り，その結果として過換気が認められた. すなわ ち心理ストレスの場合の循環機能の変化は, エネ ルギー的な変化を介しない純粋に情報的なもので あるのに対し，労作ストレスの場合はエネルギー 的な変化を介したものである。

次にこの情動性狭心症につきストレス面接を行 うと, 心拍数の増加が認められるが, $\beta$ ブロッカ
一を投与するとこの反応が抑制される ${ }^{11)}$.

Friedmanは, 被験者を行動パタン A と行動パ タン $\mathrm{B}$ に分けて, それぞれにストレス負荷を与 えたところ, 前者においてカテコールアミンの分 泌がより著しいという結果を報告している12).

以上に述べた実験結果は，いずれも情動ストレ スによって起こる生体の循環系の反応には, メデ イエーターとして，カテコールアミンないしは交 感神経系の関与のあることを示している。

\section{III. 心身医学的治療}

次に循環器心身症の治療面について述べるが, ここでは最近注目されているバイオフィードバッ ク法を中心に述べる。

バイオフィードバック法とは,「われわれがあま り意識していない身体面からの情報を、工学的な 情報の助けをかりて本人に知覚させ, その身体の 局部的反応を制御させようとする訓練法である」 と定義されている。

生体に与えられるフィードバック情報としては, 測定值をそのまま与える方法，あるいは計測值が ある值を越した時に, 視覚的, 聴覚的な信号を与 える方法等がある。

\begin{tabular}{|c|c|c|c|c|c|c|c|c|c|c|c|}
\hline & $\mathrm{HR}$ & $\begin{array}{l}\mathrm{BP} \\
(\max )\end{array}$ & $\begin{array}{l}B P \\
(\min )\end{array}$ & PH & $\mathrm{PO}_{2}$ & $\mathrm{PCO}_{2}$ & $\begin{array}{r}\text { Base } \\
\text { ex. }\end{array}$ & $\Delta \mathrm{P}$ & $\Delta \mathrm{L}$ & $L / P$ & XL \\
\hline Emotional & $\Uparrow$ & 食 & 獄 & - & & $\mathbb{1}$ & $\mathbb{1}$ & - & - & - & - \\
\hline $\begin{array}{r}\text { Physical } \\
\text { Stress }\end{array}$ & 率 & $\Uparrow$ & $\Uparrow$ & 8 & $\Rightarrow$ & & 殿 & - & 嫄 & t & $\widehat{E}$ \\
\hline
\end{tabular}

Fig. 4 情動狭心症の生理特性比較.

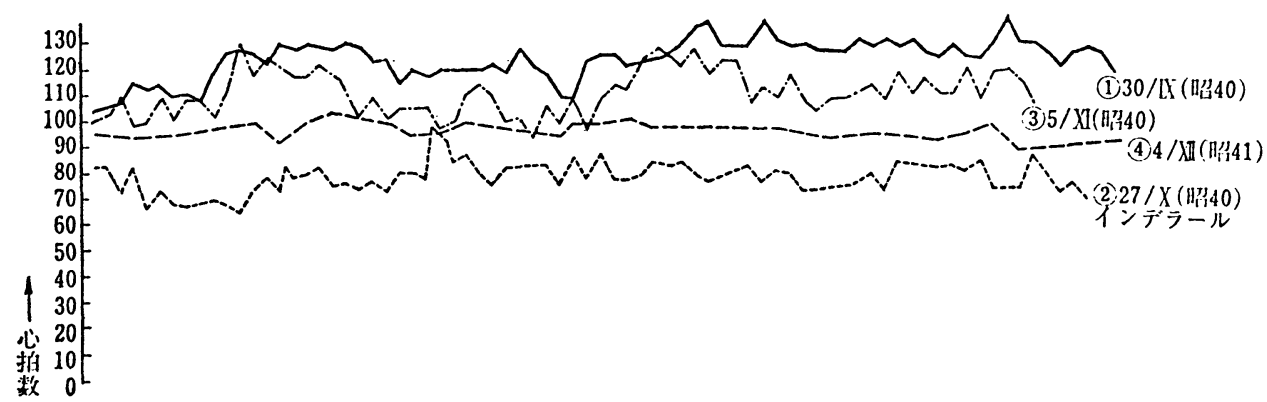

Fig. 5 面接時の心拍変動(症例 H. M. 令 58歳). 
バイオフィードバック法を初めて実験的に成功 させたのは, アメリカの心理学者N ・ミラーで, ミラーは 1960 年頃から, 動物の 自律神経領域の 機能を随意的にコントロールさせる方法について の研究を行っていた.

ミラーは, クラーレを使ってラットの随意筋を 全て弛緩させ, 人工呼吸を行い, ラットの脳の快 中枢を電気的に刺激するという報酬を用意して, ラットの心拍数をタコグラフによって測定し, そ の測定值に応じて音のシグナルを与え, 心拍数が 増加した時にのみ報酬を与えると心拍数は増加傾 向になり, 減少した時にのみ報酬を与えると減少 の傾向を示した. この他腸の収縮や弛緩, 血圧の 上昇や下降等も, バイオフィードバック法によっ てコントロールされることを明らかにした ${ }^{13)}$.

人間のバイオフィードバック法としては, 循環 器に関するものとして, ワイスとエンゲルが心拍 数について, バイオフィードバック情報によって 心拍数の増加と減少が可能であることを明らかに して, かっこのことによって, 心房性, 心室性期 外収縮をコントロールし得ることを明らかにした. そして期外収縮のコントロールは心拍数増加と減 少のいずれにおいても可能だった. われわれも, コンピューターを使って心拍バイオフィードバッ クを行い, 心拍の増加と減少に成功した.

次に人間の血圧のバイオフィードバック法だが, 本態性高血圧のバイオフィードバック法としては, 次の 3 つの方法がある.

1）筋電図バイオフィードバック法により筋緊 張を低下させる方法

2) バイオフィードバック信号として血圧值を そのまま用いる方法

3) ヨーガ等の弛緩法と数種のバイオフィード バック信号を組み合せる法

ブレナーとクライトマンは, 指にカフを巻く方 法を用いて, 収縮期血圧のみのバイオフィード バック法を行い, シャピロは上腕にカフを巻いて 収縮期と拡張期血圧のバイオフィードバック法を 行った.

そしてシャピロ, ブレナーのいずれもが, 健常 者につき血圧上昇と下降のコントロールが可能で あることを明らかにした。
インドのディティーは, 皮膚温のバイオフィー ドバック法により, 皮膚温を上昇させて二次的に 高血圧患者の血圧下降に成功した。

イギリスのペイテルは, 高血圧患者にヨーガの 呼吸法と筋弛緩練習を教えて, ついでに種々のバ イオフィードバック法, すなわち皮膚電気反応, 筋電図, 脳波バイオフィードバックを組合せて行 って, 血圧下降に成功した ${ }^{15)}$.

日本においては, 赤木, 大野らが, 心拍数およ び血圧バイオフィードバック法をはじめて行い, 石川, 菊地, 毛塚, 伊藤らも, 血圧の直接バイオ フィードバック法, 呼吸バイオフィードバック法 による二次的な血圧コントロール, 筋電図バイオ フィードバック法等により, それぞれ高血圧患者 に対する血圧下降に成功しているが，しかしこれ らの血圧下降は一時的であった ${ }^{13)}$.

\section{IV. 行動医学とサイバネーション療法}

最近アメリカで, 心身医学という概念が用いら れるようになった。

Wililamsによれば, 行動医学とは「医学と健康 と疾病の領域に対して, 行動心理学の原理と技法 を体系的に応用していくこと」とされている.

行動医学の領域は, (1) 肥満, 不眠, 頭痛, 高 血圧等に対して心理学的介入を行うこと，(2) 食 事の変化, 生活様式の変化, 服薬の問題等に関す ること, (3) 直接的な心理学的介入としてのバイ オフィードバック, (4) 疾病の予知, 予防, 健康 行動の確立と維持等である.

この行動医学の定義と目標をみると, 社会心理 的ストレスに対し, 患者がセルフコントロールす ることに重点を置いていることが判る16).

われわれは心身医学の総合的治療体系として, 気づきとセルフコントロールを原理とするサイバ ネーション療法を提唱しているが，その目標とす るところは行動医学に似ている.

すなわちサイバネーション療法の原理は，(1) ブラックボックス原理, (2) 開放系と閉鎖系の原 理, (3) フィードバック原理, (4) 情報とエネルギ 一原理からなり, 治療の実際としては, 個人サイ バネーション療法は, 自律訓練法とバイオフィー ドバック法からなり, 集団サイバネーション療法 
は，ヨーガとゲシュタルト療法からなっている.

サイバネーション療法は, 心臓神経症, 高血圧, 不整脈等の管理と予防にそれぞれ効果が認められ ている14).

以上, ストレスと動脈硬化の問題を高血圧, 冠 疾患を対象として考察した。

\section{文献}

1) Friedman, M. and Rosenman, R. H.: Association of specific Overt Behavior Pattern with Blood and Cardiovascular Findings: JAMA., 169: 1286-1296 (1959).

2) Haynes, S. G., Levine and S. Scotch N. et al.: The Relationship of Psychosocial Factors to Coronary Heart Disease in the Framingham Study-I. Method and Risk Factors. Am. J. Epidemiol, 107: 362-383 (1978).

3) 石川 中: 他高血圧の精神身体医学的研究. 精神身 体医学, 2: 162-166 (1962).

4) 石川 中：高血圧の心身医学的考察. 最新医学, 26(7): 1260-1265 (1971).

5) 石川 中, 他: Prospective Study による高血圧の 心身医学的研究. 精神身体医学, 12(4): 223-228 (1972).
6) 篠田知章：虚血性心疾患の心身の諸因子について. 心身医学, 16(2): 90-98 (1976).

7) 長谷川 清, 他: 冠状動脈疾患者のパーソナリティ 特性. 日本医事新報, 2993：43-49 (1981).

8) 保坂 隆：行動パタンと老年者虚血性心疾患. 老年 医学, 20(12): 2038-2046 (1982).

9) 石川 中, 他: JMI 健康調査法作成の試み一妥当 性の検討, 本態性動脈と心臟神経症の場合. 心身 医学, 2: 157-167 (1981).

10) 鈴木仁一, 他：心理的ストレス負荷時の心血管系反 応とカテコールアミンの動態. 精神身体医学, 14 (1): 30-35 (1974).

11）石川 中, 他：情動性狭心症の 3 例. 精神身体医学, 8(4): 248-252 (1968).

12) Friedman, M.: Psychological Factors in Cardiovascular Disorders (by Andrew Steptoe) p. 185 Academic Press London (1981).

13) 石川 中 : バイオフィードバック (I). 臨床脳波, 22 (4): 293-299 (1980).

14) 石川 中：バイオフィードバック (III). 臨床脳波, 22(6): 435-441 (1980).

15) 石川 中：バイオフィードバック (II). 臨床脳波, 22(5): 358-369 (1980).

16) Williams, R. B.: 新しい治療法としての行動医学(日 野原監記). 医学書院, 東京 (1981). 


\title{
Summary
}

\section{Stress and Arteriosclerosis}

\author{
Hitoshi IsHIKAWA
}

Department of Psychosomatic Medicine, Faculty of Medicine, Tokyo University

\section{Arteriosclerosis and character}

In hypertensive and coronary aretry disease patients, the over adaptivity to social life was found.

2. Stress and arteriosclerosis

The catecholamines and sympathetic nervous system take part in response of the cardiovascular system to emotional stress as the mediators.
3. Psychosomatic medical treatment

As the psychosomatic medical approach to the cardiovascular diseases, the biofeedback, behavior medicine, and cybernation therapy are suggested.

Key words: behavior pattern A, stress, biofeedback, behavior medicine, cybernation therapy, catecholamine. 